811.163.41'366.58

https://doi.org/10.18485/sj.2021.26.1.4

ВЕРАН Ј. СТАНОЈЕВИТ ${ }^{*}$

Универзитет у Београду

Филолошки факултет
Оригинални научни рад

Примљен: 13. 10. 2020.

Прихваћен: 12. 1. 2021.

\title{
ФОРМАЛНОСЕМАНТИЧКИ ПРИСТУП ТЕМПОРАЛНОСТИ И МОГУЋНОСТИ ЮЕГОВЕ ПРИМЕНЕ У СРПСКОМЕ ЈЕЗИКУ
}

\begin{abstract}
У раду разматрамо могућности примене формалносемантичког приступа анализи глаголских времена, који комбинује елементе Приорове темпоралне логике и Рајхенбаховог референцијалног времена, схваћеног као топикално време, на анализу времена и аспекта у српскоме језику. Глаголски вид дефинишемо клајновски, као однос времена радње и топикалног времена, што нам омогућава да и експлицитно, формалносемантички, покажемо да ни перфективност ни имперфективност нису једнозначне категорије.
\end{abstract}

Кључне речи: формална семантика, време, аспект, референцијално време, српски језик.

\section{УВОД}

Формалносемантички приступи глаголским временима трагају, између осталог, за оптималном формалном репрезентацијом темпоралне (и аспектуалне) информације коју кодирају временски глаголски облици. Појам формалне репрезентације у овоме раду треба схватити као експлицитно представљање семантичког доприноса језичких израза значењу реченица у природним језицима, али мање стриктно него у композиционалним приступима какав је,

*veranva@gmail.com 
на пример, Монтегјуова граматика (Монтегју 1973, 1974). Наиме, Монтегју је показао да је могуће дефинисати алгоритме за композиционално ${ }^{1}$ превођење реченица са природних на формалне језике ${ }^{2}$ с циљем да докаже да на плану интерпретације нема суштинске разлике између природних и формалних језика.

У формалној семантици значење реченице схвата се витгенштајновски, као скуп услова под којима је реченица истинита. Ми, наиме, реченице разумемо, тј. знамо шта значе, само ако можемо замислити ситуацију у којој су ти услови испуњени. ${ }^{3}$ При томе, не морамо знати да ли је реченица и заиста истинита (Витгенштајн 1922). Реченице, наиме, описују могуће ситуације (тј. могуће светове) у којима су истините (Портнер 2005: 16), а актуелни свет може а не мора бити једна од њих. ${ }^{4}$ Сама интерпретација реченице релативизује се на једну од таквих могућих ситуација (а то може бити и актуелни свет ${ }^{5}$ и, евентуално, на један временски моменат (који може бити и моменат говора). ${ }^{6}$

Циљ рада је да укаже на неке од најутицајнијих формалносемантичких приступа временском значењу који су допринели бољем разумевању глаголских времена у природним језицима, као и на могућности њихове примене у семантичкој анализи глаголских времена у српскоме језику.

\section{ВРЕМЕ КАО ПАРАМЕТАР ИНТЕРПРЕТАЦИЈЕ И ПРИОРОВСКИ ПРИСТУП}

Глаголска времена у природним језицима могу се схватити као инструкције да се пропозициони садржај декларативне реченице (тј. оно што се реченицом тврди) евалуира у неком моменту (или интервалу) који није

${ }^{1}$ По принципу композиционалности, који се приписује немачком логичару Готлобу Фрегеу (в. Јансен 1997), значење комплексних израза је функција значења њихових (непосредних) конституената и начина на који се они синтаксички комбинују.

${ }^{2}$ У Монтегјуовој граматици то је језик интензионалне логике.

${ }^{3}$ „To understand a proposition means to know what is the case if it is true” (Витгенштајн 1922: 4024).

${ }^{4}$ Од Карнапа (1947), фокус семантичара се помера ка могућим световима у којима екстензија реченице (тј. њена истиносна вредност) може варирати, па се значење реченице поистовећује са скупом могућих ситуација у којима је реченица истинита. По Карнаповој терминологији, која је данас стандардна у формалној семантици, такав скуп могућих светова зове се интензија реченице или пропозиција.

${ }^{5}$ Тада се питамо који услови у актуелном свету морају бити испуњени да би реченица била истинита, не улазећи у то да ли је она у актуелном свету и заиста истинита. У овом раду интерпретације реченице релативизујемо на актуелни свет и моменат говора.

${ }^{6}$ Могући свет и временски моменат с обзиром на које се реченица евалуира, односно од којих зависи њена истинитост, неки аутори, попут Каплана (Каплан 1989), зову „околностима” (circumstances) евалуације, док их други, попут Луиса (Луис 1970) зову „индексима” (indices) евалуације. 
нужно моменат говора. При том се сама реченица интерпретира с обзиром на моменат говора $\left(\mathrm{t}_{0}\right)$. Тако, у примерима под (1) и (2), које интерпретирамо с обзиром на $\mathrm{t}_{0}^{7}$, перфекат (у 1) односно футур I (у 2), сигнализују да њима уведени догађаји нису на снази у $\mathrm{t}_{0}$ него у неком прошлом, односно будућем моменту t' (види 1' и 2') који представља моменат евалуације пропозиционог садржаја анализираних реченица. Дакле, ове реченице су истините с обзиром на $\mathrm{t}_{0}$ под условом да је њихов пропозициони садржај истинит у моменту евалуације t' који је, при употреби перфекта, у прошлости, а при употреби футура - у будућности: ${ }^{8}$

(1) Марија је купила хаљину.

(1') [[Марија је купила хаљину $]^{t 0}=1$ ако и само ако постоји моменат t' антериоран моменту говора $\mathrm{t}_{0}\left(\mathrm{j} . \mathrm{t}^{\prime}<\mathrm{t}_{0}\right)$, такав да [[Марија купити хаљину] $]^{\prime}=1$

(2) Марија ће купити хаљину.

(2') $\left[[\text { Марија ће купити хаљину] }]^{10}=1\right.$ ако и само ако постоји моменат $\mathrm{t}^{\text {' }}$ постериоран моменту говора $\mathrm{t}_{0}\left(\mathrm{Tj} . \mathrm{t}^{\prime}>\mathrm{t}_{0}\right)$, такав да [[Марија купити хаљину] $]^{\prime}=1$

Глаголска времена се овде третирају као (темпорални) оператори који време евалуације (пропозиционог садржаја) реченице измештају из садашњости у прошлост или будућност 9 . Интерпретације овога типа заснивају се на неким постулатима приоровске темпоралне логике (Приор 1967). Приор је, наиме, дефинисао два оператора за прошлост $(\mathrm{P} \text { и } \mathrm{H})^{10}$ и два за будућност (F и $\left.\mathrm{G}\right)$ : Рp ('био је случај да p'), Нр ('увек је био случај да р'), Fp ('биће случај да p') и Gp ('увек ће бити случај да p'). ${ }^{11}$ У Приоровом систему нема оператора за садашњост, а то значи да одсуство темпоралног оператора евалуацију пропозиционог садржаја не измешта из садашњости (тј. из времена говорења), него је у њој задржава, што се дешава при употреби презента. Поред перфекта и футура у овоме систему могу се дефинисати и друга глаголска времена, будући

${ }^{7}$ По конвенцији, моменат говора $\left(\mathrm{t}_{0}\right)$ као индекс евалуације бележимо у горњем углу затворених дуплих заграда $[[. . .]]^{10}$. Могући свет (као други индекс евалуације) не бележимо, јер претпостављамо да се све реченице интерпретирају у актуелном свету.

${ }^{8}$ Дупле угласте заграде ([[...]]) под (1') и (2’) означавају, по конвенцији, интерпретацију примера које анализирамо, а истинитост (тј. вредност 'тачно') бележимо бројем 1 ради веће економичности, такође по конвенцији. Истиносне услове спецификује дефиниторна клауза 'ако и само ако...'.

${ }^{9}$ То практично значи да се испуњеност истиносних услова реченице проверава у неком прошлом или будућем временском моменту у зависности од употребљеног времена, а у моменту говора само при употреби тзв. индексикала (тј. деиктичких израза), као што су адверб сада или презент актуелности у примерима типа: Ja сада пишем рад за „Српски језик”.

${ }^{10}$ Симболе у целом раду бележимо латиничним словима.

${ }^{11}$ Симболом 'р' означавамо пропозициони садржај реченице, тј. нетемпорални реченични садржај који може имати неку истиносну вредност. 
да рекурзивне синтаксичке дефиниције језика темпоралне логике допуштају и комбиновање два, па и више оператора: ${ }^{12}$

(3) Марија купује хаљину. $\left([[\mathrm{p}]]^{\text {t0 }}\right)$

Другим речима, реченица под бр. (3) је истинита ако и само ако је њен пропозициони садржај (p), који представља услове њене истинитости, на снази у моменту говора.

(4) Марија је била купила хаљину. ([[PРp] $]^{\text {t0) }}$

Реченица под бр. (4) је истинита ако и само ако постоје моменти t' и t’, такви да $\mathrm{t}^{\prime}<\mathrm{t}_{0}$ и t'” $<$ ' тако да је р истинито у $\mathrm{t}$ '”

(5) (Доћи ћу) кад Марија буде купила хаљину. ([FPp] $\left.]^{10}\right)$

Реченица под бр. (5) је истинита ако и само ако постоји моменат t', такав да t'>t ${ }_{0}$ и моменат t", такав да t'”t', тако да је р на снази у t".

\section{1 Приоровски третман релативновременских употреба}

У приоровском систему могуће је представити и семантички допринос релативновременски употребљених глаголских облика. ${ }^{13}$ Тако, ако је истинита, реченица Рекао је да ће доћи значи да постоји моменат t', такав да t'< $\mathrm{t}_{0}$, и тако да $\left[[\text { он рећи] }]^{\mathrm{t}}=1\right.$ и постоји моменат $\mathrm{t}$ ", $\mathrm{t}$ " $>$ t' такав да $\left[[\text { он доћи] }]^{\mathrm{t}}=1\right.$, што значи да се релативновременски футур I (из зависне клаузе) може представити формулом: РFp ('био је случај да ће бити случај да р'). Међутим, до проблема долази онда када треба дефинисати релативновременске (у даљем тексту „релативне") употребе перфекта ${ }^{14}$, као у исказу Рећи ће да је дошао, што значи:

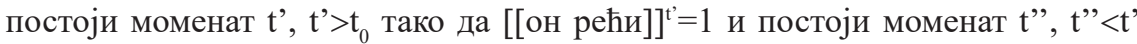
тако да $\left[[о н \text { доћи] }]^{\prime \prime}=1\right.$. Иако коректна, оваква интерпретација подразумева исту дефиницију за релативни перфекат и индикативни футур II (FPp) без обзира на разлике у њиховом значењу. Оставимо ли за сада овај проблем по страни, приметићемо да приоровски систем објашњава несамосталност футуpa II, тј. немогућност да се овај облик, сем у неким модалним контекстима ${ }^{15}$, употреби у независној реченици. У оквиру приоровског система, поменута несамосталност футура II може се објаснити неопходношћу да се ово време дефинише неком комбинацијом више темпоралних оператора. Погледајмо, у том смислу, пример (6).

12 У примерима (3-5), ради веће економичности, пропозиционом варијаблом 'p' представљамо комплетан пропозициони садржај дате реченице.

${ }^{13}$ Танасић их дефинише овако: „Када се радња јавља као истовремена, прошла или будућа у односу на неку другу радњу исказану (временским) глаголским обликом реч је о релативној временској детерминацији" (Танасић 2005: 346).

${ }^{14} \mathrm{Tj}$. употребе перфекта у односу на неку будућу радњу (в. Танасић 2005: 403).

${ }^{15}$ Као у примерима типа Можда будете успјели - види у: Ковачевић 2008: 203. 
(6) Рекао је да ће доћи кад буде доручковао.

Овде и футур I и футур II собом уведену радњу локализују постериорно у односу на радњу означену перфектом рекао је. Уз то, релативни футур II, подразумева и антериорност собом уведене радње ('доручковати') у односу на корелативну будућу радњу, уведену футуром I (ће доћu), па се мора представити формулом са три темпорална оператора: РFPp. ${ }^{16}$ Наиме, друга појавница оператора Р у формули РFРр уводи моменат $\mathrm{t}$ који означава време радње ${ }^{17}$ 'доручковати' и даје инструкцију да тај моменат треба сместити антериорно у односу на неки будући моменат t' уведен оператором $\mathrm{F}^{18}$ (тj. $\left.\mathrm{t}<\mathrm{t}^{\prime}\right)$. Тај будући моменат t', у нашем примеру, представља време радње 'доћи'. Интуитивно, то значи да футур II овде означава антериорност собом означене радње у односу на корелативну будућу радњу означену футуром I. Прва појавница оператора Р из дефиниција релативног футура I (PFp) и футура II (PFPp), уводи моменат t" који, у нашем примеру, означава време радње означене глаголом у перфекту главне реченице (рекао је), што значи да оба футура (с обзиром на присуство оператора F у својим дефиницијама) сигнализују постериорност собом означене радње (тј. времена које радња заузима) у односу на моменат t", тако да су на снази следеће темпоралне релације: t" $<$ t и t" $<\mathrm{t}$ '. ${ }^{19}$ Моменат t" може се третирати као временска перспектива у прошлости при релативним употребама времена ${ }^{20}$, у односу на коју су радње означене двама релативним футурима - постериорне. ${ }^{21}$ Приоровска интерпретација примера под бр. (6), Рекао је да ће доћи кад буде доручковао, изгледала би, неформално, овако: Реченица под бр. (6) истинита је с обзиром на моменат говора $\left(\mathrm{t}_{0}\right)$, ако и само ако постоји моменат $\mathrm{t}$ ", $\mathrm{t}$ " $<\mathrm{t}_{0}$ (што је инструкција оператора Р из формуле Рp

${ }^{16}$ Релативни футур I дефинише се, као што смо већ видели, формулом РFр.

${ }^{17} \mathrm{Tj}$. Рајхенбахов моменат догађања Е (Рајхенбах 1947).

${ }^{18}$ Наиме комбинација FРр значи: биће случај да је био случај да р (тј. p је на снази у неком моменту који је антериоран неком будућем моменту).

${ }^{19}$ Анализа футура II свакако је комплекснија од предложене, будући да у игри није само темпорална него и аспектуална семантика, тј. различите видско-временске корелације у којима, радња означена футуром II може стајати у било којој временско-таксисној релацији (симултаност, антериорност или постериорност), тј. у временском односу који се успоставља између радње зависне и радње главне реченице (в. Поповић 2018: 500-546).

${ }^{20}$ Измештање временске перспективе из садашњости у прошлост (или будућност као у примеру: Рећи ће да је дошао) у основи је релативних употреба глаголских облика у српском (в. Станојевић 2019: 286).

${ }^{21}$ Сигнализовање временске перспективе једна је од функција Рајхенбахове референцијалне тачке (R). O референцијалном времену, односно о референцијалној тачки - за чије је увођење заслужан немачки филозоф, Ханс Рајхенбах (Рајхенбах 1947) - говоримо у следећем поглављу. Рецимо овде само то да је до Кампа и Рејла (Камп/Рејл 1993) референцијална тачка служила да означи и промену временске перспективе при употреби неких времена (нпр. плусквамперфекта). Поменути аутори су функцију промене временске перспективе јасно раздвојили од референцијалне функције глаголских времена тако што су поред референцијалног времена $\mathrm{R}$, као засебан оператор постулирали и моменат временске перспективе. 
за перфекат рекао је), тако да [[он рећи] ]"=1 и моменат t', такав да $\mathrm{t}^{\prime \prime}<\mathrm{t}$ ' (што је инструкција оператора F из PFp за футур I), тако да [[он доћи] $]^{\prime}=1$ и моменат $\mathrm{t}$, такав да $\mathrm{t}<\mathrm{t}$ ' (инструкција друге појавнице оператора Р из дефиниције PFPp футура II) тако да [он доручковати] $]^{\mathrm{t}}=1 .^{22}$

Приоровски приступ, по коме се футур II дефинише путем бар два временска оператора (два за индикативне и три за релативне употребе), објашњава несамосталност овога облика, тј. нужност да се њиме означена радња темпорално веже за неку другу, корелативну радњу (в. Танасић 2005: $445)^{23}$. Тиме се објашњава чињеница да, сем у неким модалним употребама (нпр. Можда будем дошао), футур II није могуће употребити у независној реченици.

\section{3. РЕФЕРЕНЦИЈАЛНО ВРЕМЕ}

Поред проблема са приоровским дефинисањем неких релативних употреба глаголских времена, на које смо указали у одељку 2.1 овога рада, постоји и један проблем методолошке природе, а то је да се у оквиру Приоровог система не може представити тзв. референцијална функција глаголских времена. Наиме, Барбара Парти је показала да постоји извесна аналогија између глаголских времена и личних заменица, будући да, попут заменица, и времена могу имати референцијалну функцију која се, поред осталог, састоји у томе да говорно лице, при њиховој употреби, реферише (тј. упућује) на неки контекстуално проминентан, тј. истакнут моменат или временски интервал (Парти 1973) ${ }^{24}$. Пример под бр. (7), који представља незнатну модификацију оригиналног примера Барбаре Парти (op. cit.), показује да времена могу реферисати и на моменте који нису експлицитно уведени у претходном реченичном или текстуалном контексту, под условом да су познати учесницима у комуникацији. Тако, значење реченице Нисам угасио ринглу, коју изричем, рецимо, након што сам изашао из стана и већ кренуо на пут, није ни (7а) ни (7б):

(7) Нисам угасио ринглу.

(7a) Постоји моменат t’ у прошлости (тj. t'<t $)$ такав да није тачно да сам угасио ринглу у $\mathrm{t}^{\prime}$.

(7б) Не постоји ниједан моменат t' у прошлости такав да је тачно да сам угасио ринглу у $\mathrm{t}$ '.

${ }^{22}$ Појавница оператора Р из дефиниције релативног футура I (PFp) уводи исти моменат у прошлости као појавница истог оператора из дефиниције индикативног перфекта (Рp), док појавница F из дефиниције релативног футура II (PFPp) уводи исти моменат као F из дефиниције релативног футура I (PFp).

${ }^{23}$ Релацијом антериорности у примеру (6).

${ }^{24}$ у даљем тексту под термином моменат подразумевамо било моменат у смислу временског тренутка (без трајања), било интервал, тј. (конвексан) скуп временских тренутака. 
Интерпретација под (7б) очигледно је неприхватљива, јер према њој исказ под бр. (7) значи да никада (у животу) нисам угасио ринглу, што се овим исказом не тврди. Ни интерпретација под (7a), која је тривијално истинита па самим тим неинформативна, није значење примера (7). ${ }^{25}$ Исказом (7) говорник напросто тврди да ни у једном моменту једног одређеног, релативно кратког интервала (нпр. од тренутка кад је укључио ринглу да скува кафу до тренутка кад је изашао из стана) он (говорник) није угасио ринглу. ${ }^{26}$ По Барбари Парти, такав интервал је одређен ${ }^{27}$ будући да га имамо на уму и мој саговорник и ја у моменту изрицања реченице под бр. (7). Овде је перфекат употребљен деиктички ${ }^{28}$ будући да упућује на један контекстуално проминентан временски интервал у прошлости, познат актерима комуникације. Такав интервал (или моменат) који и говорник и саговорник имају на уму при употреби временских глаголских облика представља референцијално време, односно оно што је Рајхенбах (независно од овог типа примера), још раније назвао референцијалном тачком и означио симболом R у свом систему (Рајхенбах 1947).

Међутим, схватање Б. Парти по којем је референцијално време онај моменат (односно интервал) који и говорник и саговорник имају на уму (било да је експлицитно уведен ${ }^{29}$ или је само ванјезички проминентан $\left.{ }^{30}\right)$, ипак је прејако уколико се референцијално време тумачи као темпорални пандан референту (тј.

${ }^{25}$ Наиме, за било који интервал у прошлости током којег можемо констатовати да је рингла упаљена, тривијално је истинито (тј. неинформативно) рећи да постоји моменат у прошлости у којем рингла није угашена.

${ }^{26}$ Инспирисан примером под бр. (7), један од рецензената овог рада сугерише да перфекат има две референтне тачке - једну у прошлости, а другу у садашњости, те да је суштина перфекта у актуелној релевантности прошле радње. Са другим делом ове тврдње можемо се сложити, али не и са првим. Наиме, референтна тачка (тј. наше референцијално време) при употреби глаголских времена јесте моменат или интервал за који се тврди да је на снази стање ствари описано реченицом (погледати одељак 3.1 овога рада). Релевантни интервал при употреби перфекта цео припада прошлости и то без обзира што дато стање ствари (тј. неугашена рингла) може бити актуелно и у моменту говора (као у нашем примеру). Исказ Врата су била гвоздена као одговор на питање Шта си приметио кад си ушао у његов стан? свакако да подразумева да су врата гвоздена и у моменту говора, али се ипак на поменуто питање не може одговорити презентом (*Врата су гвоздена). Ствар је у томе што се питање односи на један конкретан моменат у прошлости, па се и одговор мора односити на исти тај моменат без обзира што стање ствари означено исказом важи (или може важити) и у моменту говора. Исказом под бр. (7) говорник заправо тврди да је заборавио да искључи ринглу док је био у стану, па је то време (док је био у стану) једино релевантно и представља референцијално време. Перфекат, дакле, нема две референцијалне тачке, него само једну, чак и онда када је дата ситуација (нпр. Врата су била гвоздена) на снази и у моменту говора. Моменат говора у оваквим, индикативним употребама перфекта функционише искључиво као временска перспектива, тј. моменат у односу на који се референцијално време поставља као антериорно (нпр. време од тренутка кад је говорник укључио ринглу до тренутка изласка из стана у примеру 7).

${ }^{27} \mathrm{Tj}$. референцијално одређен.

${ }^{28}$ Аналогно деиктичкој употреби заменице он чији је референт одређен (на пример, кад саговорнику кажем, показујући руком ка некој особи: Он ми је то рекао.).

${ }^{29}$ Нпр., путем временске реченице као у примеру: Кад сам ушао (R), Марија је спавала (Е).

${ }^{30} \mathrm{Y}$ смислу да га подразумева сама говорна ситуација, као у примеру (7). 
ентитету означеном путем) заменице он (или она, оно). Наиме, за разлику од референта заменице он (тј. њоме означеног ентитета) на који заменица упућује било деиктички, било анафорички и који је, самим тим, референцијално одређен, референцијално време није увек референцијално одређено. То је зато што учесници у комуникацији не морају увек имати исти моменат (интервал) на уму. Тако, српски перфекат означава по правилу неодређену прошлост, будући да при његовој употреби референцијално време (у даљем тексту R) може заузети било које место на временској оси пре момента говора, као у примеру Гледао сам тај филм, у којем перфекат сигнализује само то да сам ја дати филм гледао у прошлости и ништа више, нити прецизније од тога (нпр. у раној младости, или пре десет година, или 2018. године, или јуче, итд.). ${ }^{31}$ Другим речима, перфекат је, за разлику од аориста, неутралан у погледу временске дистанце у односу на моменат говора (уп. Танасић 2005: 424). Аорист, пак, барем у говору, подразумева темпоралну блискост времена радње у односу на моменат говора (в. Танасић 2005: 424), па је, у том смислу, њиме означена прошлост одређенија него с перфектом, иако тачно време догађаја уведеног аористом саговорник не мора знати, као у примеру Удаде му се ћерка. ${ }^{32}$

Важно је истаћи да ни временске одредбе не гарантују увек да ће перфекат прецизно локализовати глаголску радњу у време. Тако, у примеру Прошле године сам гледао тај филм, интервал уведен одредбом прошле године неупоредиво је већи од интервала који заузима уобичајено трајање радње 'гледати филм', што аутоматски отежава идентификовање момента R (за саговорника). Хипотеза коју би ваљало размотрити у неким будућим истраживањима била би следећа: Што је интервал у којем треба тражити R димензионално сличнији (тj. нешто већи или једнак) интервалу који заузима глаголска радња (нпр. Синоћ сам гледао тај филм), то је прошлост означена перфектом одређенија. Исто то важи и за будућа времена, као што је футур I (уп. Погледаћу тај филм и Вечерас ћу погледати тај филм). ${ }^{33}$

\section{1. Референцијално као топикално време и аспект}

Иако референцијално време није увек одређено - што значи да говорник и саговорник не морају имати у свести исти временски интервал у који

${ }^{31}$ У литератури се овакве употребе перфекта тумаче као искуствене (,experiential perfect”, в. Митвоч 2008).

32 Рецимо и то да је аорист овде употребљен евиденцијално, као маркер преношења информације која - и онда када није лично доживљена од стране говорника - постоји у његовој свести, па се као доживљена представља.

${ }^{33}$ Под већом или мањом одређеношћу прошлости или будућности подразумевамо факат да говорник и саговорник могу али не морају увек имати на уму исти временски интервал током којег је на снази реченицом описана ситуација. 
треба сместити глаголску радњу ${ }^{34}$ - сам концепт референцијалног времена је фундаменталан у сваком теоријском приступу глаголским временима још од Рајхенбаха ${ }^{35}$, иако га овај аутор није дефинисао. Волфганг Клајн је дао вероватно најпрецизнију дефиницију референцијалног времена, које он зове топикалним временом (Клајн 1992, 1995: 23, 2009: 46), при чему треба имати на уму да се његова концепција референцијалног времена разликује од Рајхенбахове, између осталог и по томе што оно за Клајна није моменат без трајања као за Рајхенбаха. По Клајну, топикално време (topic time) представља временски интервал за који (а не у којем) се исказом нешто тврди (Клајн 1995: 23, 2009: 46). Време за које говорник тврди да није угасио ринглу (у примеру 7) јесте, да подсетимо, интервал који се протеже од момента у коме је укључио ринглу до момента када је напустио стан. У исказу Прошле године сам се преселио, топикално време уведено одредбом прошле године у себе укључује време радње, док се питањем Шma си радио у пет сати?, од саговорника очекује да искаже радњу (нпр. Спавао сам.) која собом обухвата топикално време означено одредбом у пет сати. С друге стране, исказ $У$ nem camu caм се пробудио, значи да радња 'пробудити се' коинцидира с топикалним временом, тј. означава исти момент као и одредба y nem camu. ${ }^{36}$ Пошто не долази увек до стриктног поклапања између топикалног времена и времена радње, однос између ова два времена дефинише, по Волфгангу Клајну, аспект као граматичку категорију (Клајн 1992, 1995: 23). Време као граматичка категорија, по овоме аутору, дефинише се као однос топикалног времена према времену говорења, a (граматички) аспект као однос времена радње према топикалном времену. ${ }^{37}$

${ }^{34}$ Тако, на пример, када говорник каже Гледао сам тај филм, он зна када је гледао дати филм, што значи да је позиција момента R на временској оси за њега одређена, позната. Саговорник, пак, исти исказ интерпретира тако што, напросто, локализује R у (неодређену) прошлост у односу на моменат говора.

${ }^{35} \mathrm{Op}$. cit.

${ }^{36}$ Овде треба подсетити да топикално време не мора бити експлицитно уведено (нпр. изразима типа јуче, у пет сати итд.). Сетимо се већ анализираног примера под бр. (7) Нисам угасио ринглу, где се топикално време идентификује контекстуално (у комуникативној ситуацији), тј. где и говорник и саговорник имају на уму исти интервал. Ништа се у погледу топикалног времена не би променило ни у примерима типа Пробудио сам се и поново заспао, које нам је сугерисао један од рецензената, где сваки од перфеката подразумева сопствено топикално време, а то су два сукцесивна момента која заузимају релевантне (тренутне) радње ('пробудити се' и 'заспати').

${ }^{37}$ Не можемо се сложити са тврдњом једног од рецензената овога рада да однос времена радње према топикалном времену описује категорија таксиса. Наиме, однос време радње-топикално време на снази је увек, независно од реченичне конфигурације (независна, независносложена, зависносложена реченица) у којој интерпретирамо временске глаголске облике. Стога, без обзира имамо ли у виду изворну, Јакобсонову концепцију таксиса као темпоралне релације између радњи (симултаност, антериорност или постериорност) без реферисања на моменат говора (Јакобсон 1984: 46), или неку од савременијих, као што је концепција Људмиле Поповић по којој таксисне конструкције обухватају „искључиво реченице са формалним експонентима темпо- 
У српском језику, у којем је глаголски вид морфологизован, видску информацију изражава глаголска основа, тако да се, генерално, глаголи могу груписати у тзв. видске парове од који је један перфективан, а други имперфективан (читати-прочитати, пливати-препливати, купити-куповати итд.). У духу Клајнове теорије, аспекатска опозиција перфективно-имперфективно могла би се интерпретирати на следећи начин: ${ }^{38}$

1. Перфективни вид сигнализује да време радње (у даљем тексту VR) коинцидира са топикалним временом (у даљем тексту TV), тj. VR=TV (као

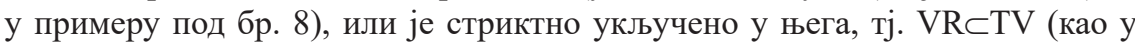
примеру под бр. 9):

(8) Прочитао сам ту књигу. (VR=TV)

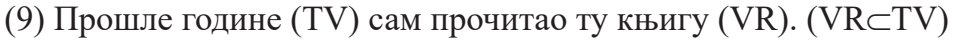

2. Са имперфективним видом ситуација је комплекснија. Имперфективни вид допушта различите релације између VR и TV, при чему VR и TV не могу бити раздвојени интервали. Тако, на пример, могућ је однос инклузије топикалног времена у време радње (тj. TV $\subset \mathrm{VR})$, што делимично одговара аспекатској подкатегорији прогресива (тј. представљању радње у току у одређеном временском моменту):

(10) У пет сати (TV) сам читао ту књигу (VR). / Кад је ушла (TV), читао

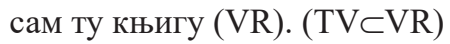

Са имперфективним видом време радње може бити укључено у топикално време, уколико је јасно да се радња, иако представљена у току, извршила у датом временском интервалу који функционише као топикално време.

(11) Јуче (TV) сам куповао намирнице (VR). / Јутрос (TV) је долазио (VR)

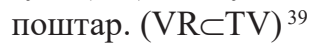

ралне оријентације главне и зависне ситуације” (Поповић 2018: 491), јасно је да је таксис доста рестриктивнија релација да би се на њу могла свести релација време радње-топикално време.

38 Овде је важно подвући да Клајнов приступ граматичком аспекту није у супротности са концепцијом аспекта као нешифтерске категорије, тј. с концепцијом која не подразумева никакву релацију између радње и времена говорења (Јакобсон 1984: 45), а самим тим ни између радње и било које друге тачке на временској оси (Комри 1976: 5). Клајново време радње (тј. „време ситуације" како га он зове) не треба схватити као време у које се радња локализује на временској оси (тј. у односу на моменат говора), него као интервал који радња заузима (тј. интервал трајања радње) и ништа више од тога. Аналогно томе, топикално време представља само интервал за који се тврди да је на снази стање ствари описано реченицом. Самим тим, однос између времена радње и топикалног времена не може бити временски, него искључиво аспекатски. Тај однос управо одговара Комријевом концепту аспекта као интерног структурирања глаголске ситуације (тј. Комријевом „интерном времену”), а компатибилан је и са концепцијом Владимира Плунгјана о виду као „прозору посматрања ситуације” (Плунгјан 2011).

39 Овакве употребе неких имперфективних глагола, на које је већ указивано у литаратури (Танасић 2009: 67, Станојевић/Ашић 2010: 122), представљају изазов за семантички третман имперфективног вида у српском језику, будући да се радње у овим примерима, иако конципова- 
Следећи пример може значити да је Марија била јако тужна цео јучерашњи дан (тj. VR=TV), а може значити и да је стање велике Маријине туге отпочело прекјуче, па се време радње преклапа са временом означеним адвербом јуче:

(12) Јуче (TV) је Марија била јако тужна (VR).

Међутим, тиме се интерпретативне могућности исказа под бр. (12) не исцрпљују, будући да није искључена ни могућност да је Марија била јако тужна јуче, али не цео дан. Наиме, сасвим је природно исказ (12) проширити на следећи начин: Јуче је Марија била јако тужна али јој се увече поправило расположење.

Имајући у виду различите интерпретативне могућности глагола имперфективног вида које илуструју примери (10), (11) и (12), претпоставићемо да се различите релације између TV и VR при њиховој употреби (тј. 'TVсVR', 'VR=TV', 'VR $\subset \mathrm{TV}$ ' или 'почетак VR претходи почетку TV'), могу обухватити релацијом преклапања времена радње и топикалног времена. Пошто су VR и TV интервали, релацију преклапања међу њима коју означавамо симболом ' ' дефинисаћемо на следећи начин:

(13) $\mathrm{VR} \sim \mathrm{TV}$ ако и само ако $\mathrm{VR} \cap \mathrm{TV} \neq \varnothing$ (тј. пресек ова два интервала није празан скуп временских момената. $\left.{ }^{40}\right)$

Може се, дакле, претпоставити да имперфективни вид у српском означава релацију преклапања два релевантна интервала: VR TV.

С друге стране, перфективни вид не искључује да пресек два интервала буде и празан скуп, односно не искључује раздвојеност топикалног времена и времена радње. Теоријски, топикално време може претходити или следити времену радње. С обзиром на то да у српском језику значење проспективности (које подразумева релацију претхођења топикалног времена, тј. TV <VR) није граматикализовано (в. Станојевић 2019: 303), једини релевантни однос међу њима јесте претхођење времена радње топикалном времену, тj. VR<TV. Тада је фокус на резултату радње, било да је тај резултат у садашњости (као у 14), у прошлости (као у 15) или у будућности (као у 16):

(14) Изашао je. ${ }^{41} \mathrm{VR}<\mathrm{TV}$ и $\mathrm{t}_{0} \subset \mathrm{TV}$ (резултативност у садашњости)

(15) Био је изамао. ${ }^{42} \mathrm{VR}<\mathrm{TV}$ и t' $\subset \mathrm{TV}$ и t' $<\mathrm{t}_{0}$ (резултативност у прошлости)

(16) Кад буде изамао ${ }^{43}$ испричаћеш ми све. VRTV и t' $\subset$ TV и t'>t ${ }_{0}$ резултативност у будућности)

не имперфективно, представљају као комплетно завршене, што је одлика свих (али очигледно не само) глагола перфективног вида.

${ }^{40}$ Подсећамо да су интервали конвексни скупови временских момената.

${ }^{41}$ У значењу 'није код куће'.

${ }^{42}$ У значењу 'није био код куће'.

43 У значењу 'кад не буде код куће'. 
Примери (14-16) илуструју резултативност у садашњости (са перфектом), резултативност у прошлости (са плусквамперфектом) и резултативност у будућности (са футуром II). ${ }^{44}$ Резултативност, дакле, подразумева релацију $\mathrm{VR}<\mathrm{TV}$, при чему TV укључује: a) моменат говора (тj. $\left.\mathrm{t}_{0} \subset \mathrm{TV}\right)$ у случају резултативног перфекта, или б) неки други моменат ( $\left.\mathrm{t}^{\prime}\right)$ у случају резултативног плусквамперфекта, односно футура II (тj. t'сTV).

Сада можемо констатовати да су у српскоме језику релевантни следећи односи између времена радње и топикалног времена:

1. $\mathrm{VR}=\mathrm{TV}$ (перфективни вид)

2. $\mathrm{VR} \subset \mathrm{TV}$ (перфективни вид)

3. VR TV (имперфективни вид)

4. $\mathrm{VR}<\mathrm{TV}$ (резултативност)

Показаћемо, на крају, како се у оквиру система који комбинује приоровски и неорајхенбаховски (тј. клајновски) приступ могу интерпретирати реченице које садрже и више од једног глаголског времена. Иако неформална, предложена семантичка интерпретација примера под бр. (17) - у бити је формалносемантичка.

(17) Кад се Јован вратио, Марија је била отишла.

Претпоставићемо да временске реченице уведене везником кад уводе топикално време (тј. време за које тврдимо да је на снази пропозициони садржај уведен главном реченицом Марија је била отишла. Претпоставићемо и то да се реченица интерпретира с обзиром на моменат (односно интервал) у којем је изричемо, тј. с обзиром на време говорења $\left(\mathrm{t}_{0}\right){ }^{45}$ Топикално време је моменат $\mathrm{t}$ уведен перфектом из зависне реченице и оно претходи моменту говора (тј. $\mathrm{t}<\mathrm{t}_{0}$ ). Пошто топикално време при употреби плусквамперфекта може следити времену радње (означене плусквамперфектом) или коинцидирати ${ }^{46}$ с њим, неопходно је одредити у каквом су односу VR и TV у примеру (17). Коинциденција VR=TV овде је неприхватљива, јер да смо хтели да је изразимо, барем апроксимативно ${ }^{47}$, употребили бисмо перфекат је отишла у главној реченици. Међутим, у том случају временско значење не би било исто као са плусквамперфектом је била отишла. Дакле, време радње уведено плусквамперфектом

${ }^{44}$ Ако аспект схватимо као фазну категорију (в. Станојевић/Ђурић 2019), у примерима (14-16) можемо говорити о резултативном аспекту, будући да је у њима акцент на постфиналној фази глаголске радње.

${ }^{45}$ По Клајну и моменат говора има статус интервала.

${ }^{46}$ Као у следећем примеру, у којем се плусквамперфекат може учинити редудантним, тј. замењивим перфектом: Био их је срео у пет сати.

${ }^{47} \mathrm{O}$ најновијем погледу на симултаност радњи уведених перфективним глаголима у зависносложеним реченицама са временским везницима кад и док, погледати рад Милоша Ковачевића (Ковачевић 2020). 
претходи топикалном времену, тако да једино резултативна интерпретација плусквамперфекта омогућава, с обзиром на Клајнову дефиницију топикалног времена ${ }^{48}$, да се главном реченицом каже нешто о топикалном времену. Резултативност, наиме, подразумева да је у комуникативном фокусу стање које произилази из догађаја ('отићи' у нашем примеру), при чему је то стање на снази у моменту $\mathrm{t}(=\mathrm{TV})$ уведеном перфектом из зависне реченице. Реченица, дакле, значи да постоји моменат $t$ у који је локализована радња 'вратити се', тако да $t<\mathrm{t}_{0}$ и интервал $\mathrm{t}$ ', током којег је на снази резултативно стање радње 'отићи', тако да $t \subset t$ '. Топикално време $t$, уједно је време евалуације пропозиционог садржаја целе реченице, што значи, да су услови истинитости ове реченице на снази у $\mathrm{t}$ ако је реченица истинита.

\section{4. ЗАКљУЧАК}

У раду смо указали на могућности примене формалносемантичког приступа анализи темпоралних и аспекатских значења глаголских времена у српскоме језику, комбинујући елементе Приорове темпоралне логике и Клајновог топикалног времена, као времена за које се исказом нешто тврди али и евалуира пропозициони садржај реченице. Моменат говора је основни параметар интерпретације, тј. време с обзиром на које се реченица интерпретира, при чему време евалуације пропозиционог садржаја реченице може бити и пре, али и после овога момента у зависности од глаголског времена. Примењујући Клајново схватање аспекта као релације између времена радње (VR) и топикалног времена (TV) на опозицију перфективни/имперфективни вид у српском, експлицитно смо показали да ни перфективни ни имперфективни глаголи нису једнозначни, тj. да не означавају једну и само једну релацију између VR и TV. Имперфективни вид је посебно семантички недетерминисан, што нас је навело да претпоставимо да се њиме изражава релација преклапања VR TV, уз услов да релевантни интервали (VR и TV) не буду раздвојени.

\section{ЛИТЕРАТУРА}

Арсенијевић 2013: Б. Арсенијевић, Временско и аспектуално значење аориста, Српски језик, XVIII, 253-263.

Вендлер 1967: Z. Vendler, Linguistics in Philosophy, Ithaca: Cornell University Press, 97-121. 
Витгнештајн 1922: L. Wittgenstein, Tractatus logico-philosophicus, London: Routledge and Kegan Paul.

Јакобсон 1984: R. Jakobson, Russian and Slavic Grammar - Studies 1931-1981, Berlin, New York, Amsterdam: Mouton Publishers.

Јансен 1997: T. M. V. Janssen, Compositionality, In: van Benthem and ter Meulen (eds.), Handbook of Logic and Language, Oxford/ Cambridge (Mass.): Elsevier / MIT Press.

Камп/Рејл 1993: Н. Kamp, U. Reyle, From Discourse to Logic. Introduction to Model-theoretic Semantics of Natural Language, Formal Logic and Discourse Representation Theory, Dordrecht: Kluwer.

Каплан 1989: D. Kaplan, On demonstratives, In: Almog, J., Perry, J. and Wettstein, H. (eds.) Themes from Kaplan, Oxford: Oxford University Press, 481-563.

Карнап 1947: R. Carnap, Meaning and Necessity, Chicago: University of Chicago Press.

Клајн 1992: W. Klein, The present perfect puzzle, Language, Vol. 68, n. 3, 525-552.

Клајн 1995: W. Klein, Frame of Analysis, (chapter 2), In: R. Dietrich, W. Klein, C. Noyau, (eds.) The Acquisition of Temporality in a Second Language, J. Benjamins, 17-29.

Клајн 2009: W. Klein, How time is encoded? In: W. Klein, Ping Li (eds.), The expression of time, Berlin, New York: Mouton de Gruyter, 39-81.

Ковачевић 2008: М. Ковачевић, Конкурентност двају футура и перфективног презента у савременом српском језику, Зборник Матице српске за славистику 73, 195-211.

Ковачевић 2020: М. Ковачевић, Симултаност перфективних предикација у зависносложеној временској реченици, Српски језик 25/1, 89-100.

Комри 1976: B. Comrie, Aspect, Cambridge University Press, 1981.

Луис 1970: D. Lewis, General semantics, Synthese 22, 18-67.

Митвоч 2008: A. Mittwoch, The English Resultative Perfect and Its Relationship to the Experiential Perfect and the Simple Past Tense, Linguistics and Philosophy 31 (3), 323-351.

Монтегју 1973: R. Montague, The proper treatment of quantification in ordinary English, In: K.J.J. Hintikka, J.M.E. Moravcsik and P. Suppes (eds) Approaches to Natural Language, 221-242. Dordrecht: Reidel.

Монтегју 1974: R. Montague, Formal Philosophy. Selected Papers of Richard Montague, New Haven/London: Yale University Press. 
Парти 1973: В. Partee, Some structural analogies between tenses and pronouns in English, Journal of Philosophy 70(18), 601-9.

Портнер 2005: P. Portner, What is meaning? Fundamentals of Formal Semantics, Blackwell Publishing, 2005.

Плунгјан 2011: В. Плунгян, Введение в грамматическую семантику, М.: РГГУ.

Поповић 2018: Љ. Поповић, Синтакса таксиса, у: П. Пипер и др., Синтакса сложене реченице у савременом српском језику, ред. Предраг Пипер, Нови Сад: Матица српска, Београд: Институт за српски језик САНУ, 2018, 491-588.

Приор 1967: A. Prior Past, Present and Future, Oxford: Clarendon Press.

Рајхенбах 1947: H. Reichenbach, Elements of symbolic logic, New York: Macmillan Co.

Станојевић 2007: В. Станојевић, Аорист у српском и у француском језику: семантичке и прагматичке разлике, Научни састанак слависта у Вукове дане, 36/1, 123-136.

Станојевиһ/Ашић 2010: V. Stanojević, T. Ašić, L'aspect imperfectif en français et en serbe, In: N. Flaux, D. Stošić, Co Vet (eds.), Interpréter les temps verbaux, Frankfurt: Peter Lang, 107-129.

Станојевић 2019: V. Stanojević, Le temps et l'aspect en français et en serbe (Bpeмe и аспекат у франиуском и српском језику), Belgrade: Faculté de Philologie de l'Université, 2019.

Станојевић/Ђурић 2019: В. Станојевић, Љ. Ђурић, Аспекат као фазна категорија и резултативност у француском и српском језику, Српски језик 24/1, 221-223.

Танасић 2005: С. Танасић, Синтакса глагола, у: П. Пипер и др., Синтакса савременога српског језика: проста реченица, ред. Милка Ивић, Београд: Институт за српски језик САНУ, Београдска књига Нови Сад, Матица српска, 345-476.

Танасић 2009: С. Танасић, Синтаксичке теме, Београд: Београдска књига. 


\section{UNE APPROCHE EN SÉMANTIQUE FORMELLE DE LA TEMPORALITÉ ET SON APPLICATION EN SERBE}

\section{Rés umé}

Ce travail présente certaines des approches les plus influentes en sémantique formelle du sens temporel de la phrase en langue naturelle. Nous envisageons une possibilité d'application d'un modèle combinant certains éléments de la logique de Prior et le point référentiel de Reinchenbach, réinterprété comme temps topical par Wolfgang Klein, au traitement du temps et de l'aspect en serbe dans le cadre général de la sémantique formelle.

Mots clé: sémantique formelle, temps, aspect, temps référentiel, le serbe.

Veran J. Stanojević 